\title{
Three-dimensional model study of the Arctic ozone loss in 2002/2003 and comparison with 1999/2000 and 2003/2004
}

\author{
W. Feng ${ }^{1}$, M. P. Chipperfield ${ }^{1}$, S. Davies ${ }^{1}$, B. Sen ${ }^{2}$, G. Toon ${ }^{2}$, J. F. Blavier ${ }^{2}$, C. R. Webster ${ }^{2}$, C. M. Volk ${ }^{3}$,

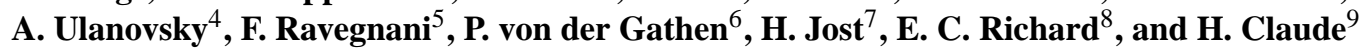 \\ ${ }^{1}$ Institute for Atmospheric Science, School of Earth and Environment, University of Leeds, Leeds, UK \\ ${ }^{2}$ NASA Jet Propulsion Laboratory, Pasadena, CA, USA \\ ${ }^{3}$ J. W. Goethe University Frankfurt, Germany \\ ${ }^{4}$ Central Aerological Observatory (CAO), Moscow, Russia \\ ${ }^{5}$ Institute of Atmospheric Sciences and Climate (ISAC), Italian National Research Council, Bologna, Italy \\ ${ }^{6}$ Alfred Wegener Institute, Potsdam, Germany \\ ${ }^{7}$ NASA Ames, Moffett Field, CA, USA \\ ${ }^{8}$ Aeronomy Laboratory, NOAA, Boulder, CO, USA \\ ${ }^{9}$ Deutscher Wetterdienst, Germany
}

Received: 21 June 2004 - Published in Atmos. Chem. Phys. Discuss.: 7 September 2004

Revised: 10 December 2004 - Accepted: 12 January 2005 - Published: 21 January 2005

\begin{abstract}
We have used the SLIMCAT 3-D off-line chemical transport model (CTM) to quantify the Arctic chemical ozone loss in the year 2002/2003 and compare it with similar calculations for the winters 1999/2000 and 2003/2004. Recent changes to the CTM have improved the model's ability to reproduce polar chemical and dynamical processes. The updated CTM uses $\sigma-\theta$ as a vertical coordinate which allows it to extend down to the surface. The CTM has a detailed stratospheric chemistry scheme and now includes a simple NAT-based denitrification scheme in the stratosphere.

In the model runs presented here the model was forced by ECMWF ERA40 and operational analyses. The model used 24 levels extending from the surface to $\sim 55 \mathrm{~km}$ and a horizontal resolution of either $7.5^{\circ} \times 7.5^{\circ}$ or $2.8^{\circ} \times 2.8^{\circ}$. Two different radiation schemes, MIDRAD and the CCM scheme, were used to diagnose the vertical motion in the stratosphere. Based on tracer observations from balloons and aircraft, the more sophisticated CCM scheme gives a better representation of the vertical transport in this model which includes the troposphere. The higher resolution model generally produces larger chemical $\mathrm{O}_{3}$ depletion, which agrees better with observations.

The CTM results show that very early chemical ozone loss occurred in December 2002 due to extremely low temperatures and early chlorine activation in the lower stratosphere. Thus, chemical loss in this winter started earlier than in the other two winters studied here. In 2002/2003 the local polar
\end{abstract}

Correspondence to: W. Feng and M. P. Chipperfield (fengwh@env.leeds.ac.uk and martyn@env.leeds.ac.uk) ozone loss in the lower stratosphere was $\sim 40 \%$ before the stratospheric final warming. Larger ozone loss occurred in the cold year 1999/2000 which had a persistently cold and stable vortex during most of the winter. For this winter the current model, at a resolution of $2.8^{\circ} \times 2.8^{\circ}$, can reproduce the observed loss of over $70 \%$ locally. In the warm and more disturbed winter 2003/2004 the chemical $\mathrm{O}_{3}$ loss was generally much smaller, except above $620 \mathrm{~K}$ where large losses occurred due to a period of very low minimum temperatures at these altitudes.

\section{Introduction}

In recent years, three-dimensional (3-D) models have been widely used to study the behaviour of ozone and other constituents during winter in the Arctic and Antarctic (e.g. Brasseur et al., 1997). Many chemical transport models (CTMs), forced by meteorological analyses, can successfully reproduce the general features of the seasonal evolution of total column ozone. However, models still fail to reproduce many aspects of polar chemistry and transport (e.g. Krämer et al., 2003; Stowasser et al., 2002). Moreover, given the large interannual variability in the Arctic it is important that any model is tested under different conditions.

Ozone loss in the Arctic stratosphere has received much attention over the past decade or so (e.g. see WMO, 2003). The significant year-to-year variability in Arctic meteorology leads to significant interannual variability in the polar ozone loss (Chipperfield and Jones, 1999). Thus, it is very difficult 
Table 1. SLIMCAT model experiments.

\begin{tabular}{llllll}
\hline Run & Resolution & $\begin{array}{l}\text { Radiation } \\
\text { Scheme }\end{array}$ & Dates & Initialisation & $\begin{array}{l}\text { Passive } \\
\text { ozone reset }\end{array}$ \\
\hline ML & $7.5^{\circ} \times 7.5^{\circ}$ & MIDRAD & $01 / 01 / 1989-28 / 04 / 2004$ & & 1 January \\
CL & $7.5^{\circ} \times 7.5^{\circ}$ & CCM & $01 / 01 / 1989-04 / 04 / 2004$ & & 1 January \\
CH99 & $2.8^{\circ} \times 2.8^{\circ}$ & CCM & $01 / 12 / 1999-19 / 04 / 2000$ & CL & 1 December \\
CH02 & $2.8^{\circ} \times 2.8^{\circ}$ & CCM & $01 / 12 / 2002-20 / 04 / 2003$ & CL & 1 December \\
MH02 & $2.8^{\circ} \times 2.8^{\circ}$ & MIDRAD & $01 / 12 / 2002-19 / 04 / 2003$ & ML & 1 December \\
CH03 & $2.8^{\circ} \times 2.8^{\circ}$ & CCM & $01 / 12 / 2003-19 / 04 / 2004$ & CL & 1 December \\
MH03 & $2.8^{\circ} \times 2.8^{\circ}$ & MIDRAD & $01 / 12 / 2003-05 / 04 / 2004$ & ML & 1 December \\
\hline
\end{tabular}

to determine the chemical ozone loss since it is masked by dynamic variability caused by reversible vertical and horizontal advection and by mixing of air masses (e.g. Grooß and Müller, 2003). In the past, many models have tended to underestimate the chemical $\mathrm{O}_{3}$ loss during cold Arctic winters (e.g. Hansen et al., 1997; Goutail et al., 1999 and Krämer et al., 2003). Some of these also appear to overestimate the chemical loss during warm winters (e.g. Guirlet et al., 2000). Previous studies also indicate that current CTMs cannot give a satisfactory observed partial column ozone loss (e.g. Rex et al., 2004). All these conclusions are based on the fact that the CTMs cannot reproduce the observed ozone. In fact, successful quantitative simulation of ozone loss depends critically on the realistic combination of horizontal and vertical transport, chemistry, radiative transfer and other processes which must be correctly represented in the models.

In this paper we examine the performance of our recently updated SLIMCAT model in the Arctic stratosphere. We use it to investigate the Arctic chemical ozone loss in 2002/2003 and compared it with the winters 1999/2000 and 2003/2004. Section 2 describes the updated model and experiments performed. The different meteorological conditions related to the polar ozone loss for the three winters are presented in Section 3. Section 4 shows our model results including sensitivity studies to the different radiation scheme and horizontal resolution. We also show how significant improvements were made in the new updated model when compared with observations especially for the cold Arctic winters 1999/2000 and 2002/2003. Section 5 summarises our conclusions.

\section{Model and experiments}

\subsection{SLIMCAT 3-D CTM}

SLIMCAT is an off-line 3-D CTM first described in Chipperfield et al. (1996). The original version of SLIMCAT used pure isentropic levels as a vertical coordinate and was thus limited to the domain above $\sim 330 \mathrm{~K}(\sim 9 \mathrm{~km})$. The new version of SLIMCAT (Chipperfield, in preparation, 2005 ${ }^{1}$ ) is now formulated using a hybrid $\sigma-\theta$ vertical coordinate, which means that it can extend down to the surface. Horizontal winds and temperatures are specified using meteorological analyses. Vertical advection is calculated from diabatic heating rates using a radiation scheme. The original SLIMCAT used the MIDRAD middle atmosphere radiation scheme (Shine, 1987) to determine the cross-isentropic flow since the lowest model vertical level was $\sim 330 \mathrm{~K}$. In this case the lower boundary to the radiation scheme was $700 \mathrm{hPa}$ where climatological upwelling long-wave fluxes are specified in order to model reasonable heating rates above $\sim 100 \mathrm{hPa}$. With the extension of the model to the surface the use of MIDRAD is likely no longer appropriate and we have added alternative radiation schemes including code based on the NCAR CCM (Briegleb, 1992). This scheme (hereafter called 'CCM') uses a $\delta$-Eddington approximation (Joseph et al., 1976) and accurately computes absorbed solar radiation when compared to available reference calculations and observations (Briegleb, 1992). The downward and upward fluxes in the CCM radiation scheme can extend from $1000 \mathrm{hPa}$ to the top of atmosphere.

Chemical tracers in SLIMCAT are advected using the scheme of Prather (1986) which conserves second-order moments. The model contains a detailed gas-phase stratospheric chemistry scheme (Chipperfield, 1999). The runs used here are based on photochemical data from JPL 2003 (Sander et al., 2003) with the exception of the absorption cross sections of $\mathrm{Cl}_{2} \mathrm{O}_{2}$ which were taken from Burkholder et al. (1990) extrapolated to $450 \mathrm{~nm}$. The model also contains a treatment of heterogeneous reactions on liquid aerosols, nitric acid trihydrate (NAT) and ice (see Chipperfield, 1999). For the runs used here a simple NAT-based denitrification scheme was included in the model which assumes NAT forms in two modes. This is the same as the scheme described by Davies et al. (2002) and tested for the cold winter of 1999/2000.

\footnotetext{
${ }^{1}$ Chipperfield, M. P.: A new version of the TOMCAT/SLIMCAT off-line chemical transport model, Q. J. Roy. Met. Soc., in preparation, 2005.
} 

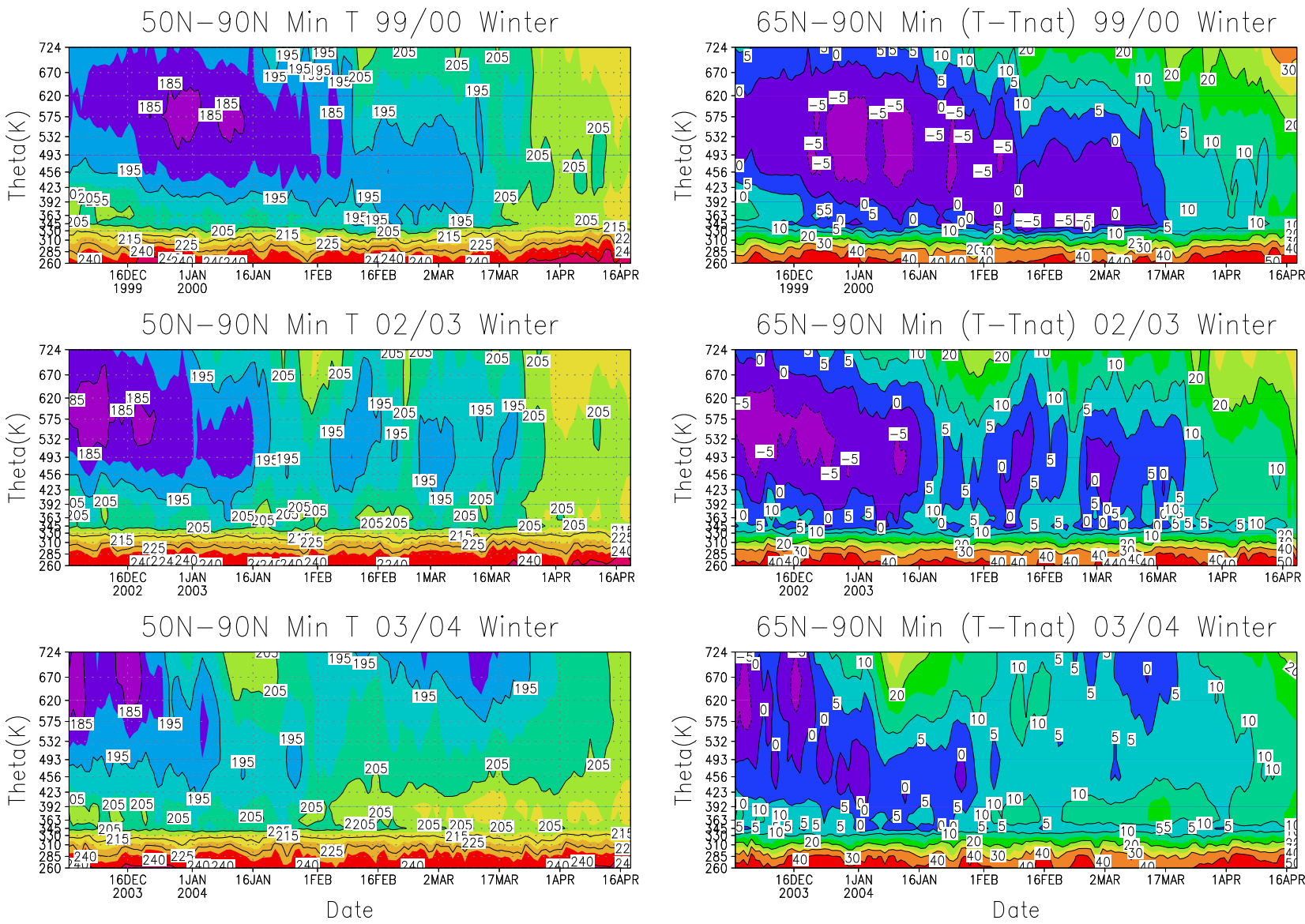

Fig. 1. The evolution of minimum temperature $(\mathrm{K})$ northward of $50^{\circ} \mathrm{N}$ (left) and minimum difference between temperature and the equilibrium NAT formation temperature (T- $\mathrm{T}_{N A T}, \mathrm{~K}$ ) northward of $65^{\circ} \mathrm{N}$ (right) as a function of time and $\theta$ in Arctic winters $1999 / 2000$, 2002/2003, and 2003/2004. $\mathrm{T}_{N A T}$ was calculated based on model $\mathrm{H}_{2} \mathrm{O}$ and $\mathrm{HNO}_{3}$ using the expression of Hanson and Mauersberger (1988).

\subsection{Experiments}

A series of full chemistry model runs were performed to investigate the performance of the updated SLIMCAT model (see Table 1). First, in runs ML and CL, SLIMCAT was initialised on 1 January 1989 and integrated at low horizontal resolution $\left(7.5^{\circ} \times 7.5^{\circ}\right)$ for $\sim 14$ years using 6-hourly ECMWF analyses. These runs used ERA40 reanalyses from 1989 to 1999 and then operational analyses from 1 January 2000 onwards. The model used 24 levels from the surface to $\sim 55 \mathrm{~km}$ with a resolution in the lower stratosphere of $\sim 1.5-2 \mathrm{~km}$. Run ML used the MIDRAD radiation scheme while CL used the CCM radiation scheme. The surface values of tropospheric source gases $\left(\mathrm{CH}_{4}, \mathrm{~N}_{2} \mathrm{O}\right.$, halocarbons) were specified from WMO (2003) and an extra 100 pptv of chlorine and 6 pptv of bromine were assumed to reach the stratosphere from short-lived $\mathrm{Cl} / \mathrm{Br}$ source gases (see WMO, 2003). The resulting halogen loadings in 2002 are around 3.7 ppbv Cly and 21 pptv Bry.
Output from these low resolution runs were taken and interpolated to a higher horizontal resolution $\left(2.8^{\circ} \times 2.8^{\circ}\right)$ to initialise seasonal simulations for winters 1999/2000, $2002 / 2003$ and 2003/2004. These seasonal runs were forced with ECMWF operational analyses throughout (runs CH99, $\mathrm{CH02,} \mathrm{MH02}, \mathrm{CHO3}$ and MH03, see Table 1). As well as providing the current best estimate of SLIMCAT modelled polar $\mathrm{O}_{3}$ depletion for these winters, these experiments investigate how the model radiation scheme and horizontal resolution affect the calculation of chemistry and transport in the polar winter/spring.

\section{Meteorology in the three Arctic winters}

The evolution of minimum temperatures is frequently used to provide an overview of the times favouring PSC formation (e.g. Manney et al., 1994; Feng et al., 2005). Figure 1 shows time series of minimum temperatures north of $50^{\circ} \mathrm{N}$ between $260-724 \mathrm{~K}$ (surface to $\sim 28 \mathrm{~km}$ ) from 1 December to late April in the years 1999/2000, 2002/2003 and 2003/2004. 

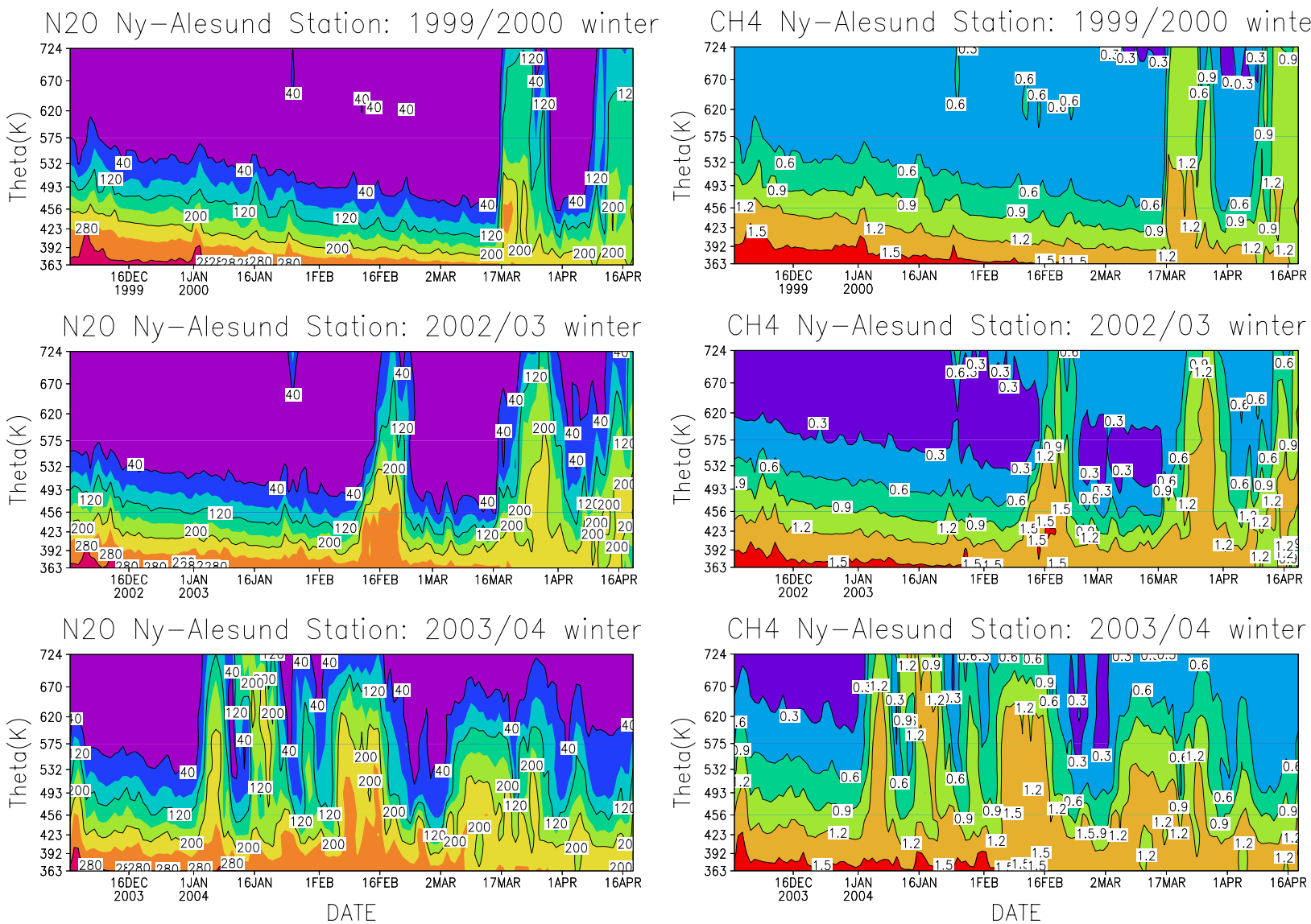

Fig. 2. Model $\mathrm{N}_{2} \mathrm{O}$ (ppbv) and $\mathrm{CH}_{4}$ (ppmv) at $\mathrm{Ny}$ - $\AA$ lesund station $\left(79^{\circ} \mathrm{N}, 12^{\circ} \mathrm{E}\right)$ from SLIMCAT runs $\mathrm{CH} 99$, $\mathrm{CH} 02$, and $\mathrm{CH} 03$ (CCM, high resolution) as a function of time and $\theta$ for the three Arctic winters (top: 1999/2000, middle: 2002/2003, bottom: 2003/2004).

averaged $\mathrm{N} 2 \mathrm{O}$ inside vortex at $456 \mathrm{~K}$

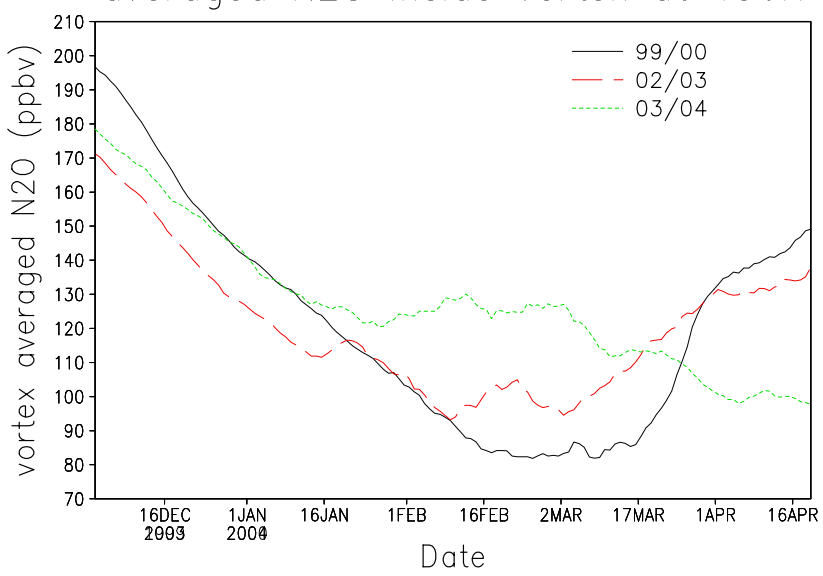

Fig. 3. Time series of the averaged modelled $\mathrm{N}_{2} \mathrm{O}$ inside the polar vortex at $456 \mathrm{~K}$ from runs $\mathrm{CH} 99, \mathrm{CH} 02, \mathrm{CH} 03$ for Arctic winters 1999/2000, 2002/2003 and 2003/2004.
In the $1999 / 2000$ winter, low temperatures $\left(\mathrm{T}_{\min } \leq 195 \mathrm{~K}\right)$ occurred persistently above $450 \mathrm{~K}(\sim 17 \mathrm{~km})$ and descended with time reaching below $400 \mathrm{~K}(\sim 14 \mathrm{~km})$ in January. Minimum temperatures were below $185 \mathrm{~K}$ between 532 $620 \mathrm{~K}(\sim 22-26 \mathrm{~km})$ during the period from late December to mid-January. The final stratospheric sudden warming occurred in late March. The year 2002/2003 can also be classed as an extremely cold early Arctic winter (e.g. Naujokat and Grunow, 2003). Extremely low temperatures occurred from early December until mid-January and the coldest air around 6 December 2002 coincided with the area of an observed $\mathrm{O}_{3}$ minihole around Scandinavia (e.g. http://www.ozone-sec. ch.cam.ac.uk/EORCU/Reports/wr0203.pdf). Temperatures increased in late January then decreased again in early February. A stratospheric minor warming occurred in midFebruary followed by a further cooling in late February and early March. The final warming began in late March. The 2003/2004 Arctic winter was warmer than these other years. Low temperatures ( $\mathrm{T} \leq 195 \mathrm{~K})$ occurred from 1 December to early January above $460 \mathrm{~K}(\sim 18 \mathrm{~km})$ and there was short cold period in late January. Another interesting point was the 

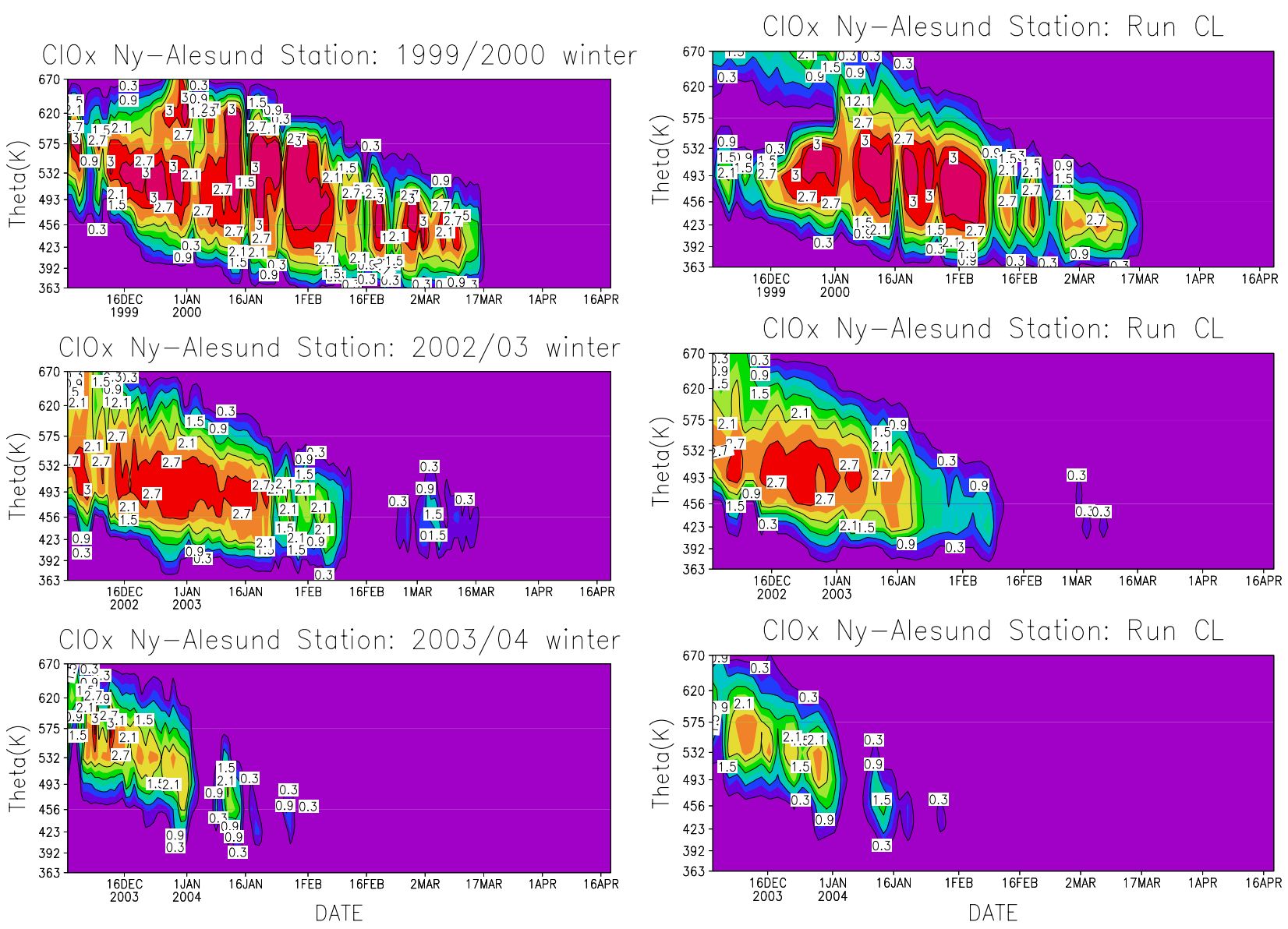

Fig. 4. Modelled $\mathrm{ClO}_{\mathrm{x}}\left(=\mathrm{ClO}+2 \mathrm{Cl}_{2} \mathrm{O}_{2}\right)$ (ppbv) at $\mathrm{Ny}$ - $\mathrm{Allesund}\left(79^{\circ} \mathrm{N}, 12^{\circ} \mathrm{E}\right.$ ) for the Arctic winters $1999 / 2000$ (top), 2002/2003 (middle) and 2003/2004 (bottom). The left panels show results from the higher resolution runs (top run CH99 (CCM), middle run CH02 (CCM) and bottom run $\mathrm{CHO}(\mathrm{CCM})$ ) and the right panels show results from the low resolution multiannual run CL (CCM).

extremely cold period between mid February and mid March at higher altitudes above $620 \mathrm{~K}(\sim 26 \mathrm{~km})$. The analyses from the U.K. Met Office (UKMO) (Swinbank and O'Neil, 1994) also captured the abnormal cold period for this winter (Y. Orsollini, personal communication, 2004).

Figure 1 (right) shows the difference between minimum temperature and the equilibrium NAT formation temperature $\left(\mathrm{T}_{N A T}\right)$ in the polar region. Negative values of $\mathrm{T}^{-} \mathrm{T}_{N A T}$ show the possible PSC occurrence as a function of time and altitude. For these three winters, the altitude of possible PSCs gradually descended with time after 1 December. Clearly, PSCs occurred extensively during the 1999/2000 Arctic winter - a large reduction in PSCs occurred only after mid March 2000 due to the stratospheric warming. In 2002/2003 the main period of possible PSCs occurred from December 2002 until mid January 2003. Other occasional PSC formation occurred around 8 February and 1 March 2003. However, much less PSC activity occurred in the winter 2003/2004.

Due to their long chemical lifetimes in the stratosphere nitrous oxide $\left(\mathrm{N}_{2} \mathrm{O}\right)$ and methane $\left(\mathrm{CH}_{4}\right)$ can be used to study stratospheric dynamics. Their time evolution can provide information on the vertical and horizontal transport of air masses. Figure 2 shows the evolution of modelled $\mathrm{N}_{2} \mathrm{O}$ and $\mathrm{CH}_{4}$ (from the higher resolution seasonal simulations) at $\mathrm{Ny}$-Ålesund station $\left(79^{\circ} \mathrm{N}, 12^{\circ} \mathrm{E}\right)$ for the three winters 1999/2000, 2002/2003 and 2003/2004. Clearly, in $1999 / 2000$ the vortex remained stable and located over NyÅlesund station for most of the winter. The disturbed vortex occurred only after 17 March 2000 due to the final stratospheric warming. In winter 2002/2003, the polar vortex was also stable before mid February but became more disturbed after that due to the minor stratospheric warming. The vortex returned over the station again from late February to mid March 2003 when the temperatures were again low. In contrast to the cold winters of 1999/2000 and 2002/2003, the polar vortex in 2003/2004 was much more disturbed for most of the time after January. Such a warm, disturbed polar vortex is not so conducive to large chemical ozone loss.

Figure 3 shows the time series of averaged $\mathrm{N}_{2} \mathrm{O}$ inside the vortex at the $456 \mathrm{~K}$ isentropic level where there is strong 


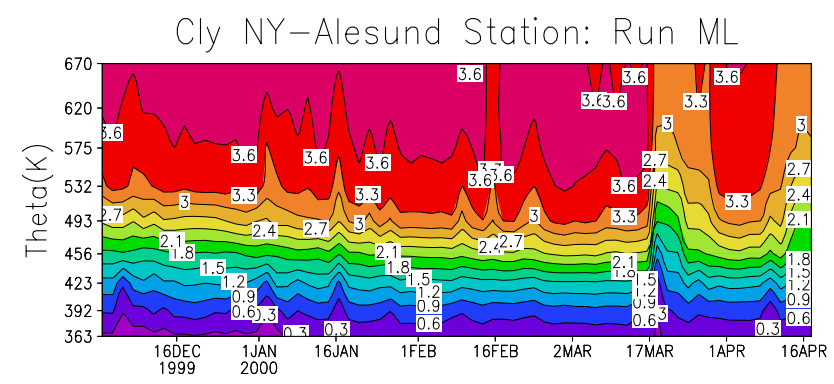

Cly NY-Alesund Station: Run CL
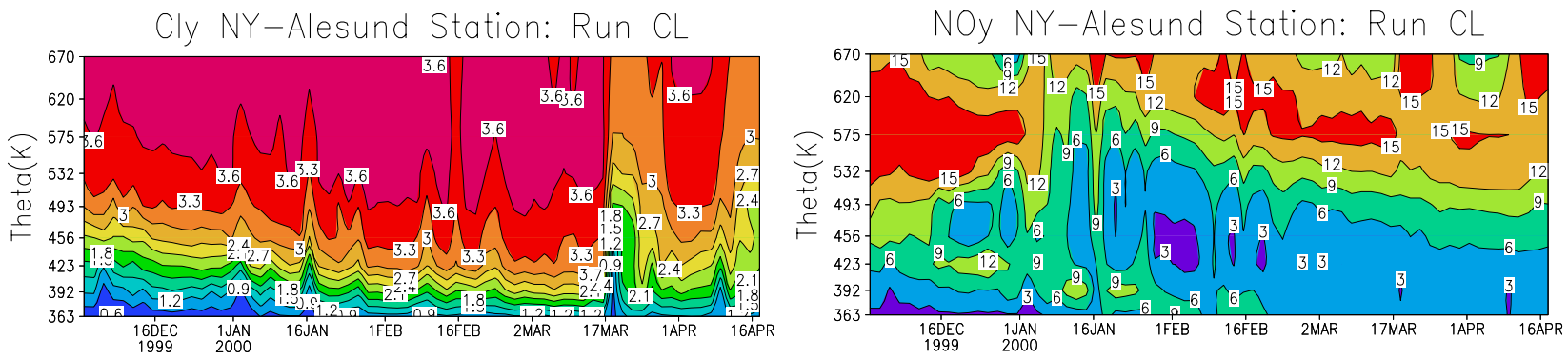

Cly NY-Alesund Station: Run CH

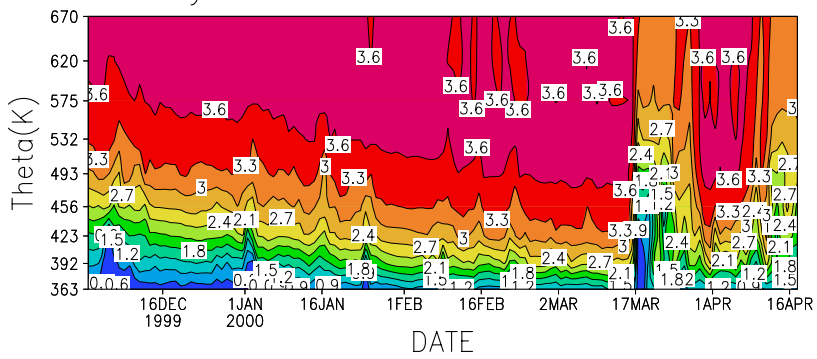

NOy NY-Alesund Station: Run CH

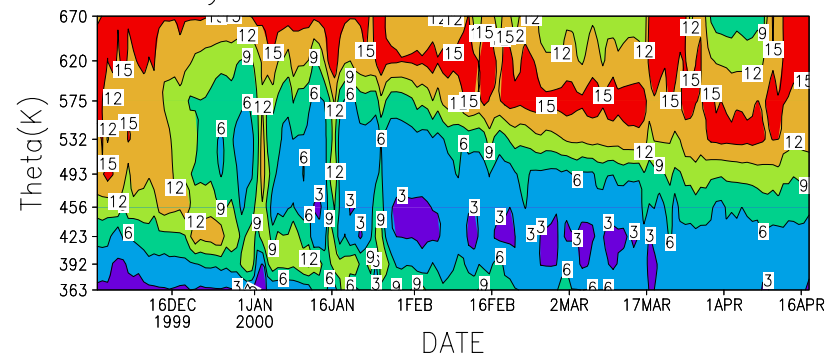

Fig. 5. Modelled $\mathrm{Cl}_{\mathrm{y}}$ (ppbv, left) and $\mathrm{NO}_{\mathrm{y}}$ (ppbv, right) at $\mathrm{Ny}$-Ålesund $\left(79^{\circ} \mathrm{N}, 12^{\circ} \mathrm{E}\right)$ for the Arctic winters $1999 / 2000$ for run ML (MIDRAD, low resolution) (top - $\mathrm{Cl}_{\mathrm{y}}$ only), run CL (CCM, low resolution) (middle) and run CH99 (CCM, high resolution) (lower).

vortex edge and large ozone loss for the three winters. Here the vortex is defined as the area enclosed by the $67^{\circ} \mathrm{N}$ effective latitude (EL) contour. The evolution of this averaged tracer is a combination of both descent and mixing at the vortex edge. Clearly, the descent in the 1999/2000 winter was stronger, and extended over a longer period, than other two winters due to the stable and cold polar vortex. $\mathrm{N}_{2} \mathrm{O}$ values increased rapidly after 17 March 2000 due to the stratospheric warming and vortex break-up. For the Arctic winter $2002 / 2003$, the $\mathrm{N}_{2} \mathrm{O}$ values inside the vortex decreased rapidly in early December, increased after mid-January, and then decreased again until the vortex elongated and split from 13 to 25 Febrary 2003. There was less descent in the Arctic winter 2003/2004 than the other two winters during the period from mid January to mid March due to its warmer temperature. However, average $\mathrm{N}_{2} \mathrm{O}$ continues to decrease from mid March to mid April.

\section{Results}

4.1 Chlorine activation: Effect of meteorology and model resolution

Chlorine activation plays a key role in the polar ozone loss (e.g. see WMO, 2003). Figure 4 (left) shows the modelled $\mathrm{ClO}_{\mathrm{x}}\left(=\mathrm{ClO}+2 \mathrm{Cl}_{2} \mathrm{O}_{2}\right)$ at $\mathrm{Ny}$-Ålesund as a function of time and $\theta$ for three years. Here the results are from the $2.8^{\circ} \times 2.8^{\circ}$ resolution model using the CCM radiation scheme. For the three winters, chlorine activation occurred from early December and activation gradually descended consistent with the corresponding low temperatures and likely PSC extent (Fig. 1). In the year 2002/2003, much more chlorine activation occurred in early December and even extended down to $400 \mathrm{~K}$ around 6 December. A more rapid deactivation followed the minor warming after mid February (not shown). Then, reactivation occurred during the period from late February to mid March 2003 due to the cooling of polar air masses and potential PSC occurrence. The chlorine activation on PSCs lasted longer in the year 1999/2000 due 


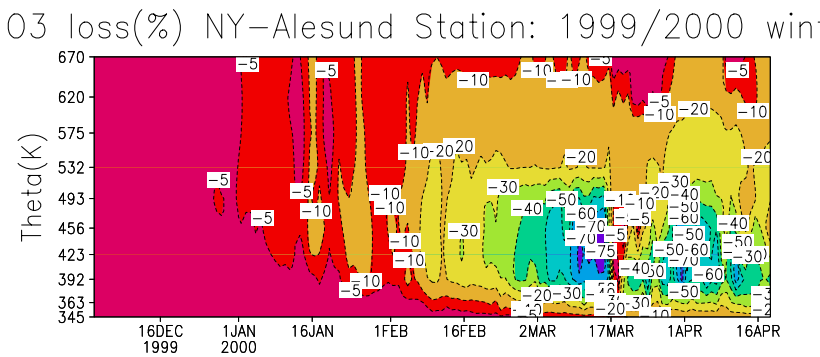

03 loss(\%) NY-Alesund Station: 2002/03 winte
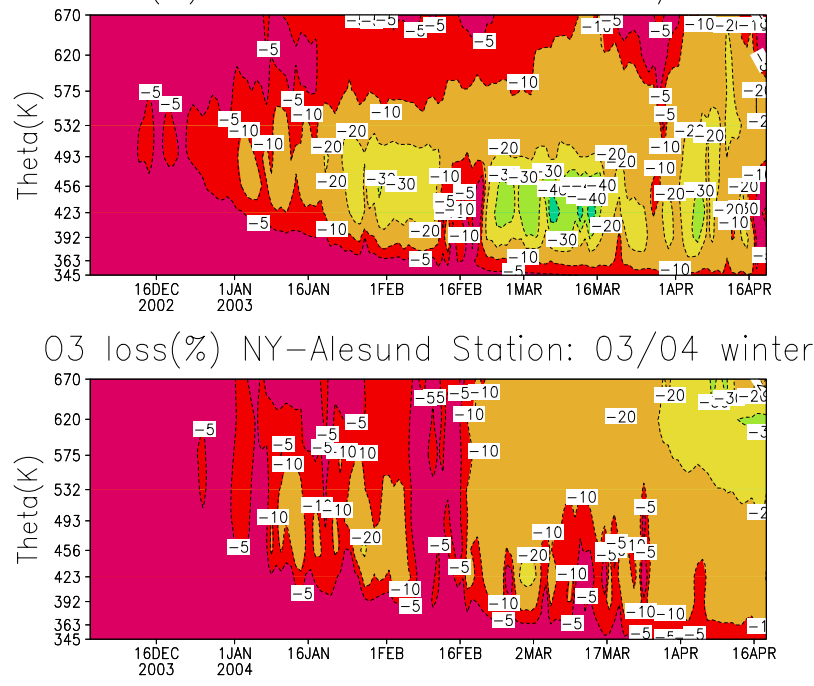

Fig. 6. As Fig. 4 (left), but for \% local ozone loss.

to the persisting stable polar vortex and lower temperatures. In contrast, in 2003/2004 the activation occurred over a much shorter period and at higher levels from early December until late January.

The right panels in Fig. 4 show the equivalent plots from the low resolution multiannual run CL. The features are generally similar to the higher resolution runs. The differences in $\mathrm{ClO}_{\mathrm{x}}$ in December 1999 near $600 \mathrm{~K}$ are due to the different analyses used in the two experiments during this month: run CL used ERA40 analyses until 1 January 2000 while run CH99 used the operational analyses. Late on in this winter (i.e. early March) the $\mathrm{ClO}_{\mathrm{x}}$ values in the higher resolution run persist with higher values. Figure 5 shows that the higher concentrations of $\mathrm{ClO}_{\mathrm{x}}$ are partly due to higher $\mathrm{Cl}_{\mathrm{y}}$ concentrations, caused by stronger descent and less mixing, and partly due to the stronger denitrification found in the higher resolution run.

The different chlorine activation largely determines the different ozone loss. Figure 6 shows the local ozone loss at Ny-Ålesund station for the three modelled winters. Larger ozone depletion occurred in the year of 1999/2000, aided by more denitrification which delayed chlorine deactivation to $\mathrm{ClONO}_{2}$. Ozone loss in the warm 2003/2004 winter is generally much smaller, but abnormally large above $620 \mathrm{~K}$ due to the period of very low minimum temperatures above this

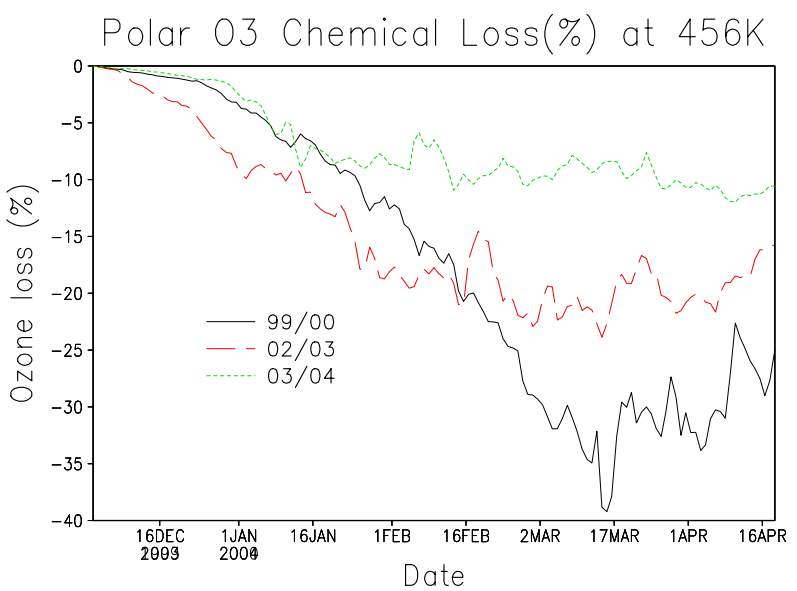

(a)

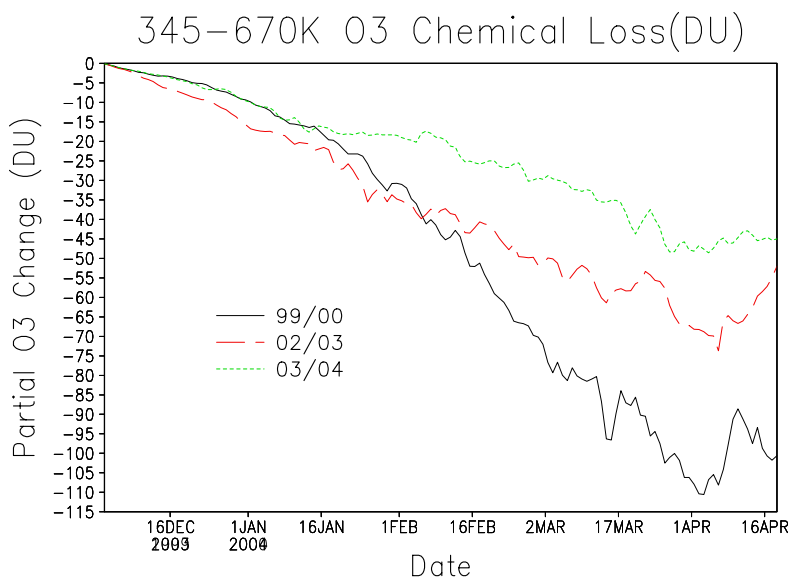

(b)

Fig. 7. Time series of averaged chemical ozone loss for (a) $456 \mathrm{~K}$ (\%) and (b) 10 to $26 \mathrm{~km}$ partial column (DU) between equivalent latitudes $65^{\circ}-90^{\circ} \mathrm{N}$.

altitude. In 2002/2003 the local maximum ozone loss at NyÅlesund was about $40 \%$ of the initial 1 December value before the final warming. Figure 6 also shows that early local ozone loss occurred in December due to more activation on PSCs and extremely low temperatures.

Figure 7 shows time series of averaged chemical ozone loss at $456 \mathrm{~K}$ and partial column ozone loss $(\sim 10-26 \mathrm{~km})$ between equivalent latitudes $65^{\circ}-90^{\circ} \mathrm{N}$. The averaged polar $\mathrm{O}_{3}$ loss is less than the local ozone loss at $\mathrm{Ny}$-Ålesund shown above. At $456 \mathrm{~K}$ there is an average $\sim 25 \%$ chemical $\mathrm{O}_{3}$ loss by the end of March for 2002/2003 and about $10 \%$ ozone loss for $2003 / 2004$, with no further ozone loss after mid February 2003. The maximum polar ozone loss in the year $1999 / 2000$ reached about $40 \%$ at $456 \mathrm{~K}$. The figure again shows the early chemical loss in December 2002 due to the low temperature and early chlorine activation. The partial column ( $\sim 10$ to $26 \mathrm{~km})$ ozone chemical loss reached 15 DU by the end of December and about 65 DU by the end of March in the winter 2002/2003. In the year 1999/2000, larger 


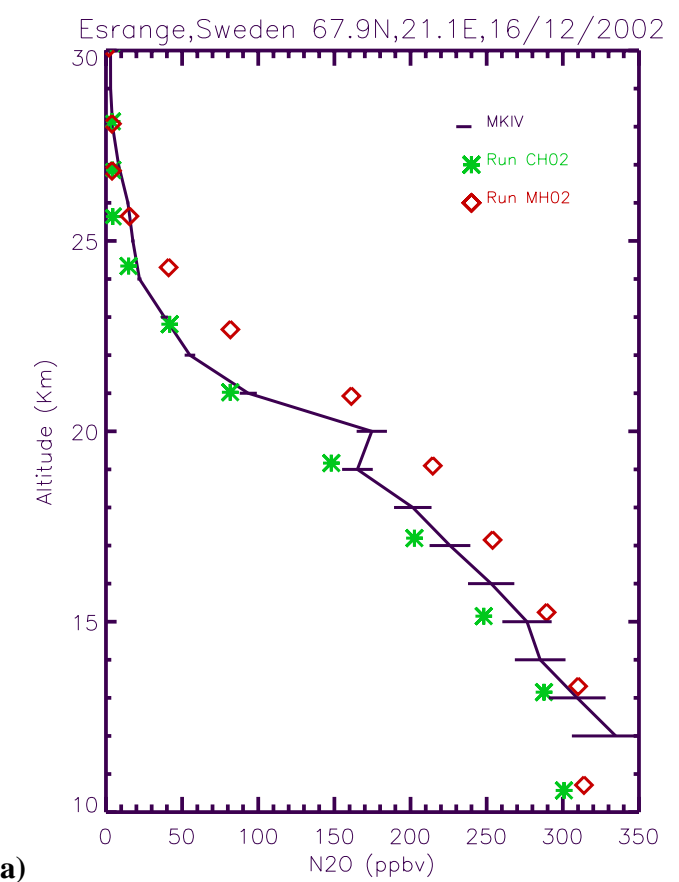

(a)
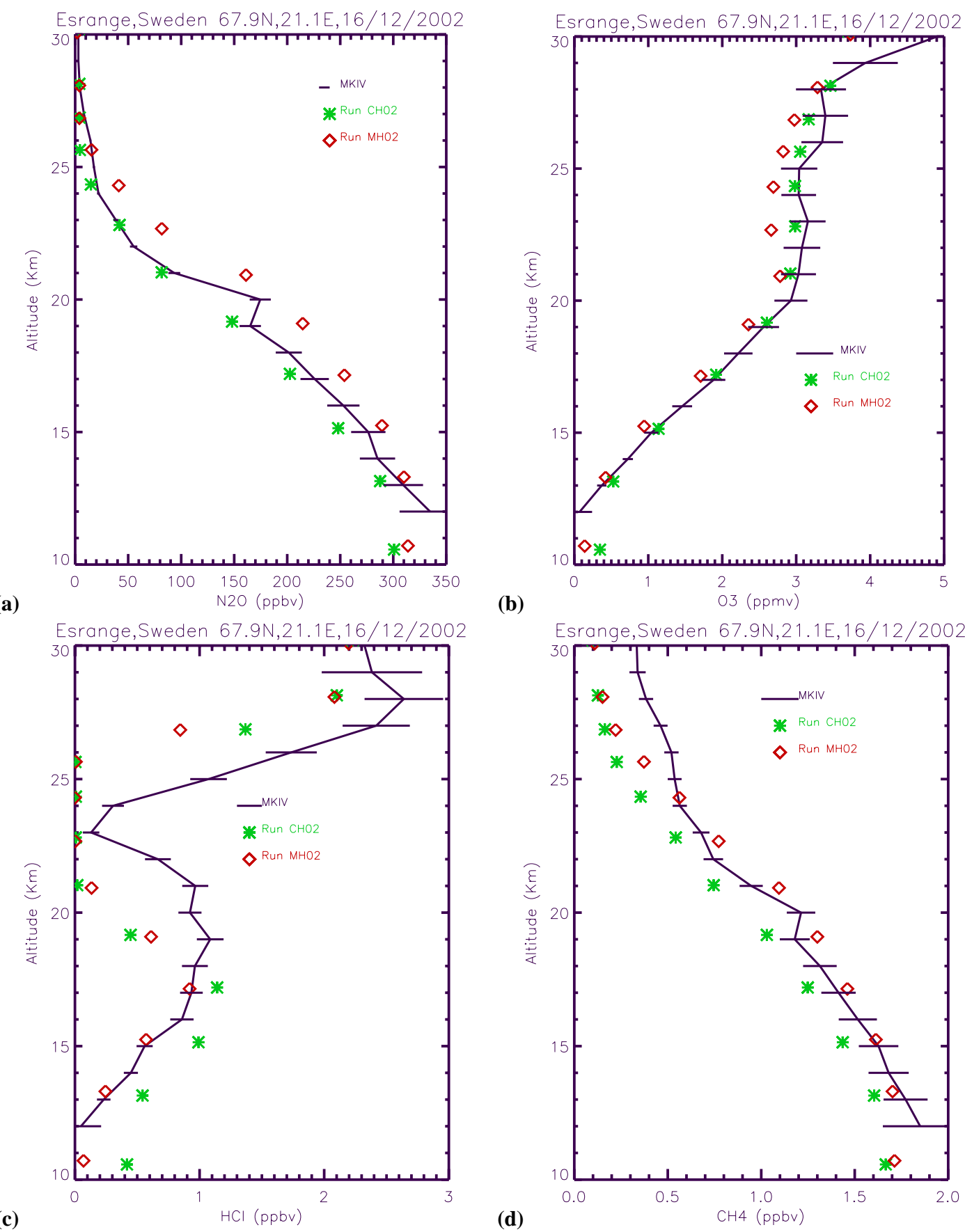

(b)

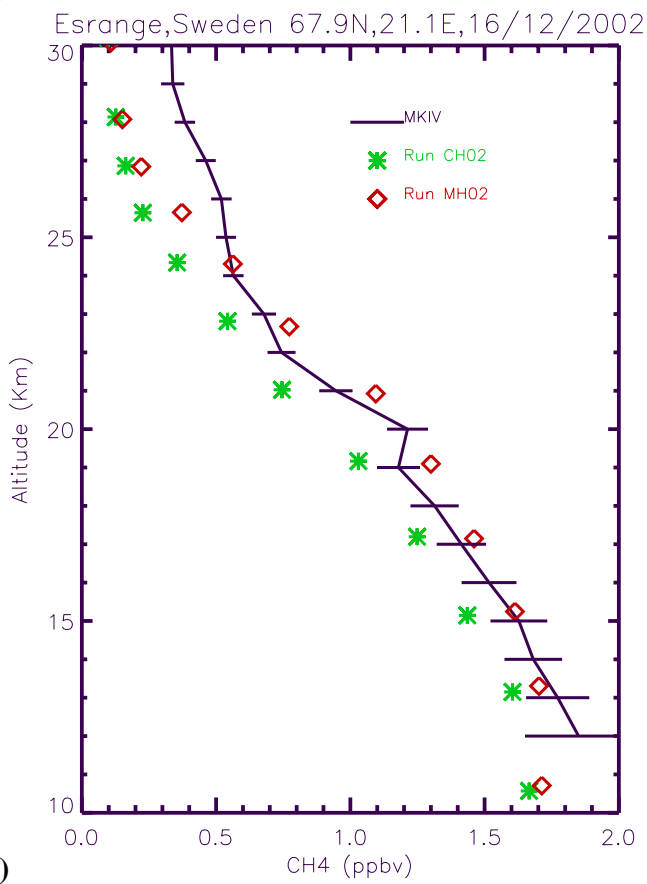

Fig. 8. MkIV balloon observations of (a) $\mathrm{N}_{2} \mathrm{O}$ (ppbv), (b) $\mathrm{O}_{3}$ (ppmv), (c) $\mathrm{HCl}$ (ppbv) and (d) $\mathrm{CH}_{4}$ (ppmv) at Esrange (68 $\left.8^{\circ} \mathrm{N}, 21^{\circ} \mathrm{E}\right)$ on 16 December 2002 along with results from SLIMCAT model runs CH02 (CCM, high resolution) and MH02 (MIDRAD, high resolution).

chemical ozone loss occurred and reached about 100 DU by the end of March. While less chemical ozone loss occurred in the warm and more disturbed winter 2003/2004, the partial column ozone loss between $345 \mathrm{~K}-670 \mathrm{~K}$ is about $40 \mathrm{DU}$ by the end of March 2004.

\subsection{High latitude descent: Comparison with data for} 2002/2003 and 1999/2000

The differences in the model results for runs ML and CL (for more details see Sects. 4.3 and 4.4), which differ only in the scheme used to diagnose vertical transport, clearly indicate the need to test these runs against tracer observations. Some balloon and aircraft observations are available for the 
winter 2002/2003 and many more are available for winter 1999/2000.

Figure 8 shows profiles observed by the MkIV balloon instrument (Toon, 1991) on 16 December 2002 along with SLIMCAT output from the higher resolution simulations for 2002/2003 winter (run CH02 and run MH02). The profiles of long-lived species $\mathrm{N}_{2} \mathrm{O}$ and $\mathrm{CH}_{4}$ can be used to verify the modelled tracer transport. Downward transport is strongly underestimated by the SLIMCAT run using MIDRAD (run MH02) based on the $\mathrm{N}_{2} \mathrm{O}$ profile comparison. The model run using the $\mathrm{CCM}$ radiation scheme (run $\mathrm{CH} 02$ ) gives more descent than run MH02. However, the modelled $\mathrm{CH}_{4}$ from run $\mathrm{CH} 02$ has lower values than the observations, which may be caused by the lower model tropospheric $\mathrm{CH}_{4}$. The surface values of tropospheric source gases $\left(\mathrm{CH}_{4}=\sim 1.76 \mathrm{ppmv}\right.$, $\mathrm{N}_{2} \mathrm{O}=\sim 316$ ppbv) were specified from WMO (2003), and this determines the origin of the $\mathrm{CH}_{4}: \mathrm{N}_{2} \mathrm{O}$ correlation. With this boundary condition the model cannot reproduce both the observed $\mathrm{CH}_{4}$ and $\mathrm{N}_{2} \mathrm{O}$ simultaneously. Simulations using the more realistic CCM radiation scheme for diagnosing diabatic descent (run $\mathrm{CH} 02$ ) more accurately reproduces the observed ozone profile from the MkIV balloon than the MIDRAD scheme (run MH02).

Comparisons with in-situ aircraft observations during $2002 / 2003$ also show similar results. Figure 9 shows an example of one M55 Geophysica flight for 26 January 2003. The Geophysica aircraft flew at between $\sim 18 \mathrm{~km}$ and $\sim 20 \mathrm{~km}$, corresponding to $\sim 450 \mathrm{~K}$ and $\sim 500 \mathrm{~K}$. The aircraft dived to $\sim 14 \mathrm{~km}$ when it reached northward of $75^{\circ} \mathrm{N}$. The operational ECMWF temperatures used in the model compare well with observations. The transport, in particular the descent of air masses, is well reproduce by the model using $\mathrm{CCM}$ radiation scheme (run $\mathrm{CHO2}$ ) when compared with the observed $\mathrm{N}_{2} \mathrm{O}$ measured on board the M55 by the HAGAR instrument (Volk et al., 2000; Riediger et al., 2000). Similar results from other flights comparisons (not shown here) also indicate that the model run using MIDRAD radiation scheme (run MH02) underestimates the descent of air masses. Reasonable diabatic descent also gives a better simulation of ozone. Figure 9 also shows that $\sim 0.5-0.7$ ppmv ozone loss occurred at $18 \mathrm{~km}$ and $\sim 0.6 \mathrm{ppmv}$ loss at $20 \mathrm{~km}$ from run $\mathrm{CH} 02$. Less ozone loss is diagnosed from run $\mathrm{MH02}$; different vertical descent of air masses in the polar vortex can significantly affect vertical transport of ozone.

Figure 10 shows the evolution of the averaged $\mathrm{N}_{2} \mathrm{O}$ inside the vortex for 2002/2003 Arctic winter/spring using MIDRAD, the CCM radiation scheme and their relative difference. Obviously, the structures of modelled $\mathrm{N}_{2} \mathrm{O}$ inside the polar vortex are very similar when using the CCM and MIDRAD radiation schemes (e.g. the sharp gradient in modelled $\mathrm{N}_{2} \mathrm{O}$ after mid Februrary due to the split of vortex and intrusion of midlatitude air). The relative modelled $\mathrm{N}_{2} \mathrm{O}$ difference between using CCM (run CH02) and MIDRAD (run MH02) radiation schemes can be used to show when and where the two runs diverge over the course of the winter.

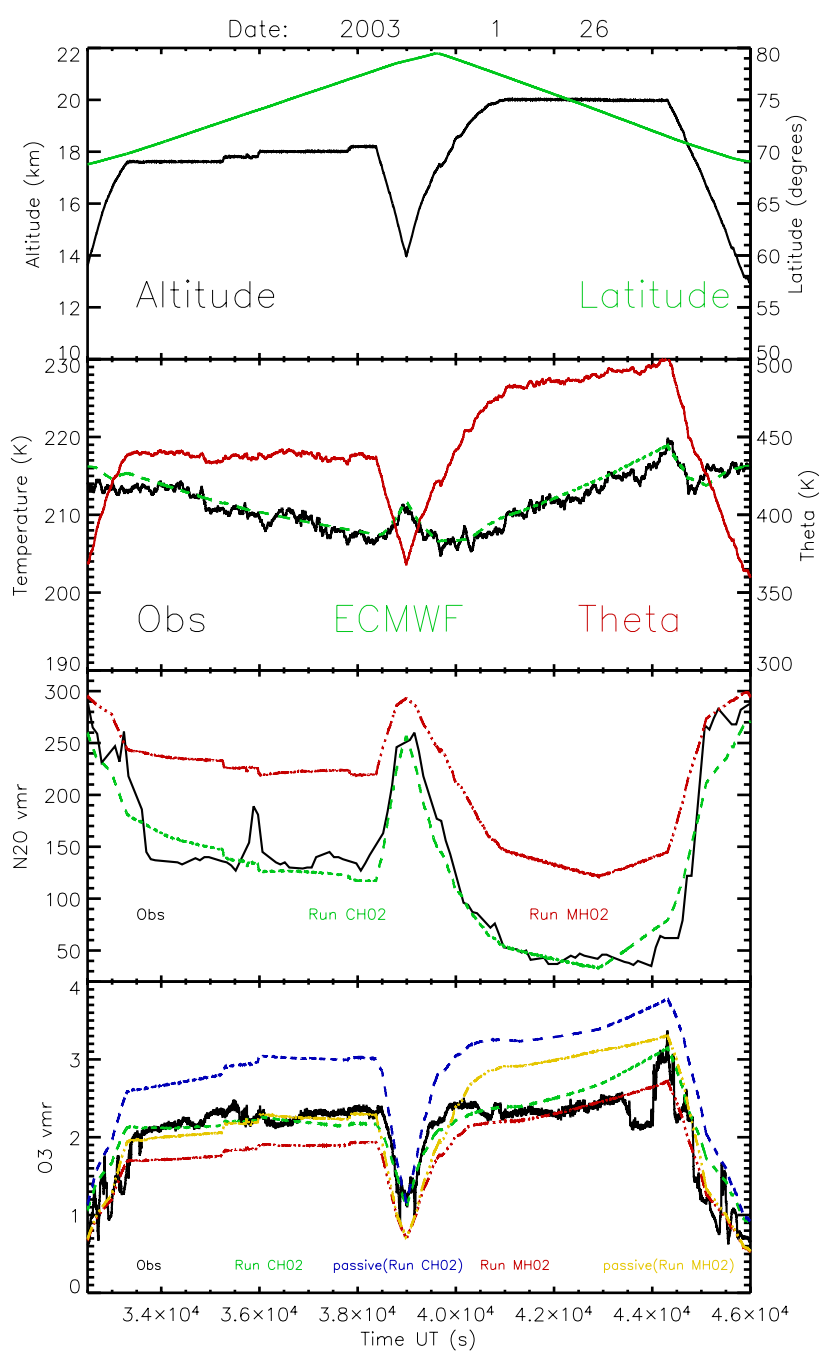

Fig. 9. Observations from the M55 Geophysica flight of 26 January 2003 compared with SLIMCAT model runs. (a) Latitude and altitude of flight track. (b) Observed and model (ECMWF) temperature and calculated $\theta$. (c) Observed HAGAR $\mathrm{N}_{2} \mathrm{O}$ (ppbv) (solid black line) and model results from runs $\mathrm{CHO} 2$ (CCM, high resolution) and MH02 (MIDRAD, high resolution). (d) Observed FOZAN $\mathrm{O}_{3}$ (ppmv) (solid black line) and model $\mathrm{O}_{3}$ and passive $\mathrm{O}_{3}$ (ppmv) from runs CH02 (CCM, high resolution) and MH02 (MIDRAD, high resolution).

Clearly, there was difference between $\sim 425 \mathrm{~K}$ and $\sim 620 \mathrm{~K}$ after five days run, and the maximum difference reached about $80 \%$ relative to modelled $\mathrm{N}_{2} \mathrm{O}$ value from run $\mathrm{CH} 02$. This also shows that overall the model run using the CCM radiation scheme (run $\mathrm{CH} 02$ ) gives more descent than run MH02 in the lower stratosphere.

Figure 11 compares the higher resolution model with the CCM radiation scheme with tracer data from winter 1999/2000. The data comes from the ER-2 flight of 11 March 2000 where the aircraft flew inside the polar vortex near the start and at the end of the flight (Konopka et al., 2004). The model reproduces the magnitude of observed $\mathrm{N}_{2} \mathrm{O}$ and $\mathrm{CH}_{4}$ 


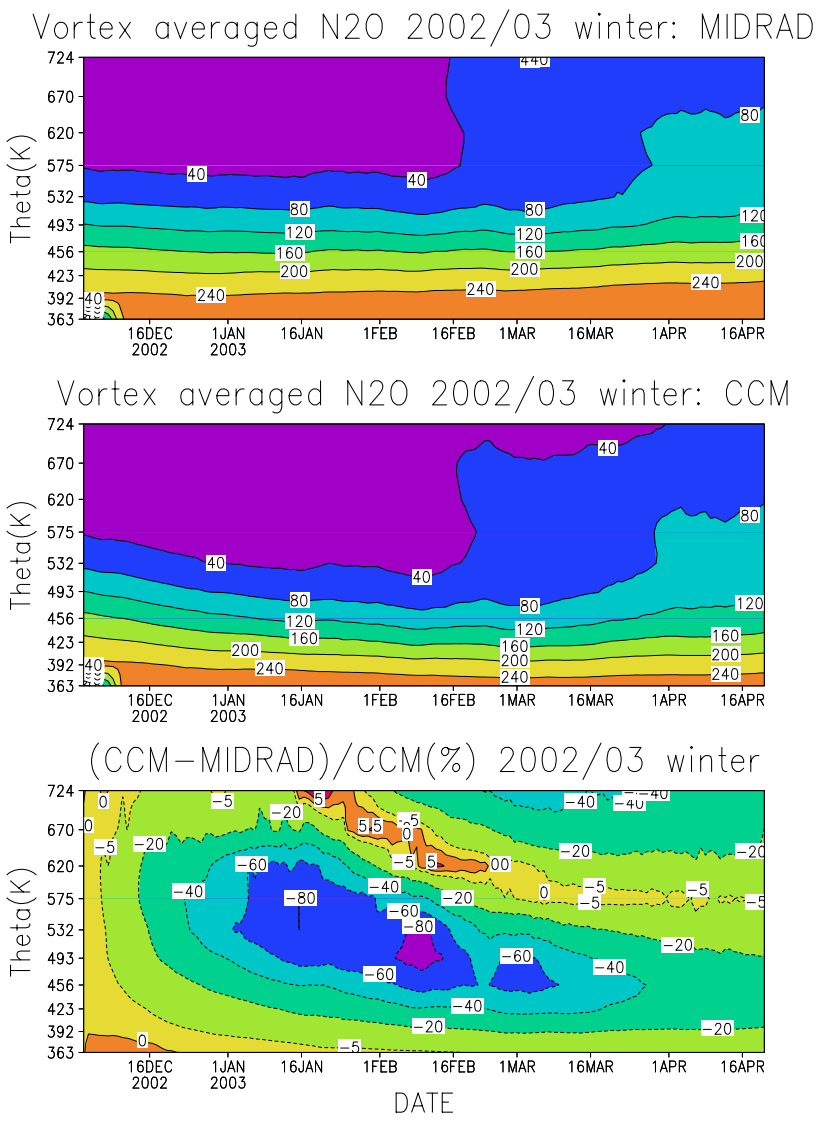

Fig. 10. Evolution of the averaged modelled $\mathrm{N}_{2} \mathrm{O}$ (ppbv) inside the vortex and the relative difference $(\%)$ between the runs $\mathrm{CHO} 2$ and MH02 for Arctic 2002/2003 winter/spring: top run MH02, middle run $\mathrm{CH} 02$ and bottom relative difference.

inside the vortex, as well as the gradient at the vortex edge. This supports the conclusion that this model setup gives a realistic representation of transport in the lower stratosphere.

\subsection{Winter 1999/2000: comparison with ozone sondes}

As a number of updates have been made to the SLIMCAT model we also compare it with $\mathrm{O}_{3}$ sonde observations in 1999/2000. Previous studies with SLIMCAT have shown a good agreement between the model and the observed large depletion in the lower stratosphere in this cold winter (Sinnhuber et al., 2000). These older runs used the purely $\theta$-coordinate model and were forced by UKMO analyses. As discussed by Davies et al. (2002), although these simulations produce a realistic extent of chlorine activation (based on comparisons with in-situ aircraft data) this was partly due to denitrification caused by ice sedimentation which was facilitated by the erroneously cold UKMO temperatures for this winter. Similar simulations with ECMWF analyses for 1999/2000 did not give such large $\mathrm{O}_{3}$ loss and the UKMOforced model underestimated $\mathrm{O}_{3}$ loss in previous cold winters (e.g. 1996/1997).

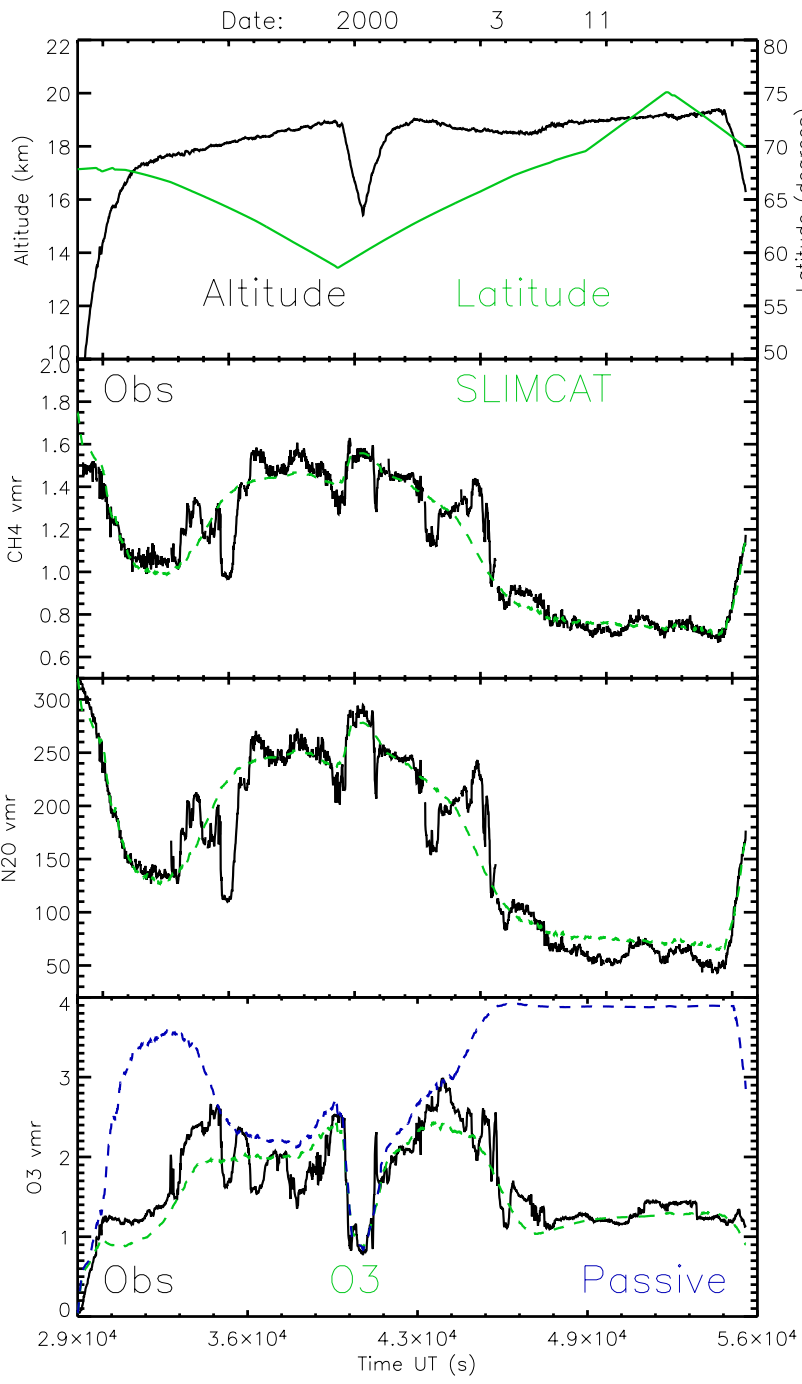

Fig. 11. Observations from the ER-2 flight of 11 March 2000 compared with SLIMCAT model run CH99 (CCM, high resolution). (a) Latitude and altitude of flight track. (b) Observed and modelled $\mathrm{CH}_{4}$ (ppmv). (c) Observed and modelled $\mathrm{N}_{2} \mathrm{O}$ (ppbv). (d) Observed and model $\mathrm{O}_{3}$ (ppmv) along with passive $\mathrm{O}_{3}$ (blue).

Figure 12 compares $\mathrm{O}_{3}$ sonde observations at $\mathrm{Ny}$-Ålesund with model runs for 1999/2000 (see Table 1). Clearly, the low resolution, multiannual run starting in 1989 using the MIDRAD radiation scheme (run ML) underestimates the observed $\mathrm{O}_{3}$ at the start of the winter (e.g. by $\sim 0.5 \mathrm{ppmv}$ at $460 \mathrm{~K}$ and $425 \mathrm{~K}$ in December). Run ML gives a poor simulation for 1999/2000 Arctic winter. While the old (pure $\theta$ ) version of SLIMCAT, with a lower boundary at $330 \mathrm{~K}$ was able to use MIDRAD successfully, the new model as used here extends down to the surface although MIDRAD was developed for use in the middle atmosphere only. MIDRAD cannot be expected to accurately calculate the upward radiative fluxes from the troposphere. 


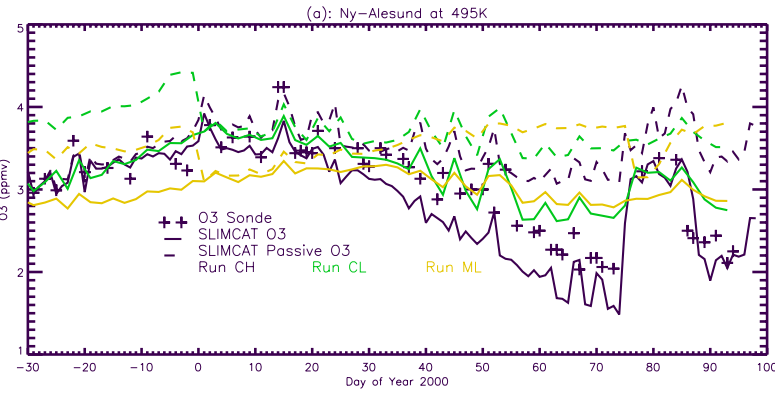

(a)
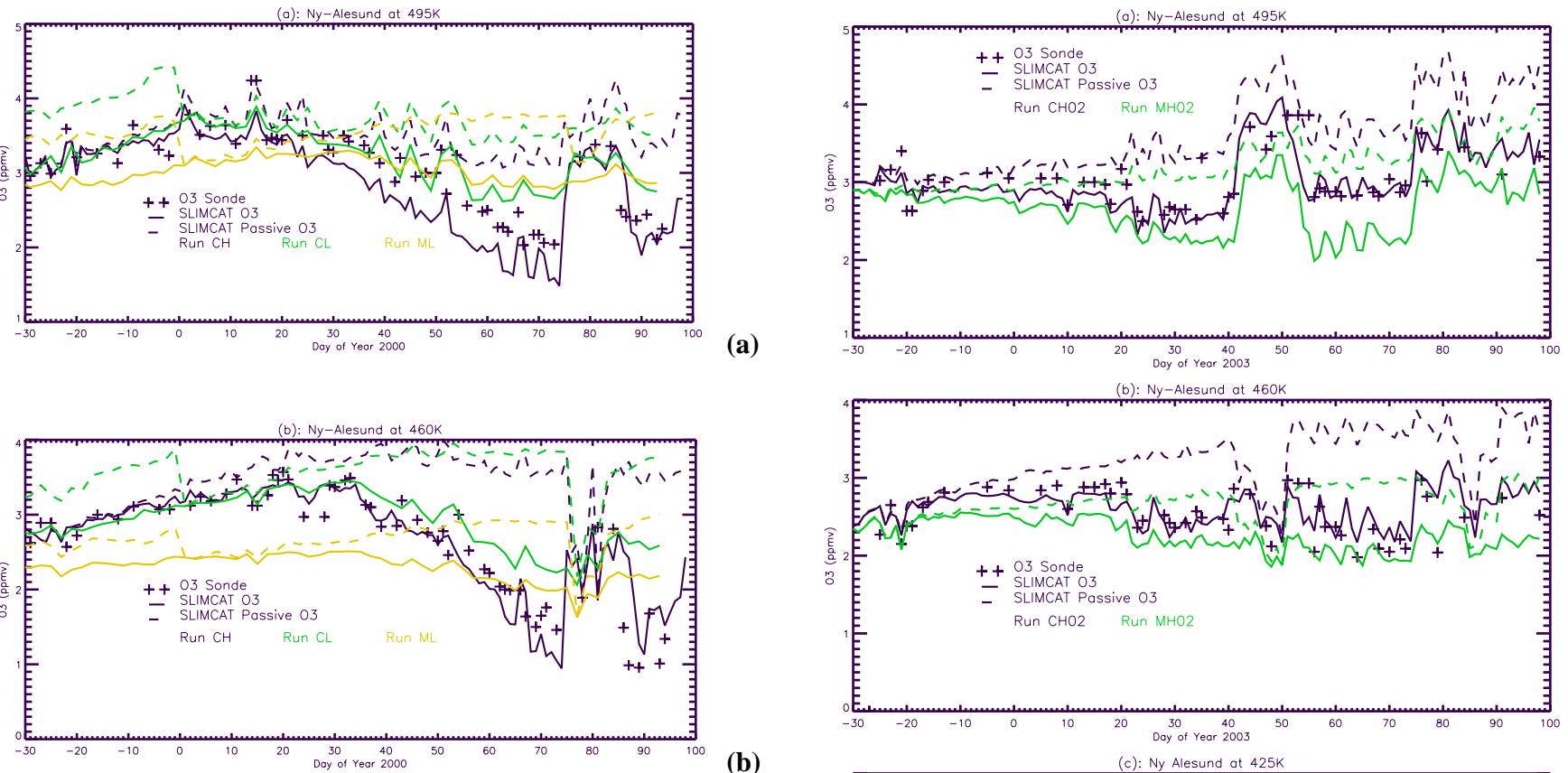

(b)
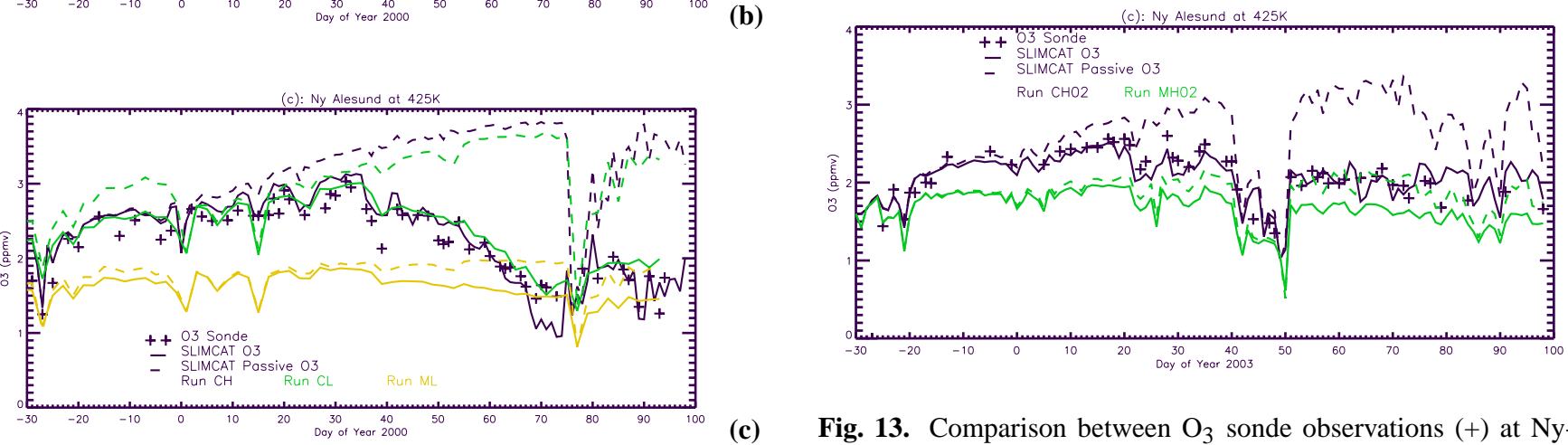

(c)

Fig. 12. Comparison of $\mathrm{O}_{3}$ sonde observations (+ marks) at Ny-Ålesund for 1999/2000 with results for SLIMCAT runs ML (MIDRAD, low resolution), CL (CCM, low resolution) and CH99 (CCM, high resolution) for $\theta$ levels (a) $495 \mathrm{~K}$, (b) $460 \mathrm{~K}$ and (c) $425 \mathrm{~K}$. The dashed lines indicate the passive model $\mathrm{O}_{3}$ tracer.

Figure 12 also shows results using the CCM radiation scheme. The $\mathrm{O}_{3}$ simulation by the new version of SLIMCAT using the CCM radiation scheme (run CL) clearly gives better results than run ML. The calculated ozone in run CL reproduces the observations in early December 1999 (after ten years of spin up) and successfully reproduces the large observed decrease in ozone at $425 \mathrm{~K}$. However, this low resolution multiannual simulation overestimates the observed $\mathrm{O}_{3}$ above $450 \mathrm{~K}$ after late February. The figure also shows the model passive ozone tracer. This is reset equal to the chemically integrated $\mathrm{O}_{3}$ in early winter (1 January for run ML and run CL, see Table 1) and then advected passively without chemistry. At any point and time after that the difference between this passive $\mathrm{O}_{3}$ and the model's chemically integrated $\mathrm{O}_{3}$ tracer is the net chemical $\mathrm{O}_{3}$ loss. Run ML

Fig. 13. Comparison between $\mathrm{O}_{3}$ sonde observations (+) at $\mathrm{Ny}-$ Ålesund and results from the $2.8^{\circ} \times 2.8^{\circ}$ resolution SLIMCAT runs CH02 (CCM, high resolution) and MH02 (MIDRAD, high resolution) for winter 2002/2003 (top: $495 \mathrm{~K}$, middle: $460 \mathrm{~K}$, bottom: $425 \mathrm{~K})$.

using MIDRAD calculates less polar ozone loss than run CL using CCM radiation scheme.

A further significant improvement is made by the higher resolution $\left(2.8^{\circ} \times 2.8^{\circ}\right)$ seasonal simulation using the CCM radiation scheme (run $\mathrm{CH} 99$ ). The initialisation from run $\mathrm{CL}$ is good and the higher resolution run captures the decrease up to day 70 better and also has lower $\mathrm{O}_{3}$ when the vortex comes back over the station around day 90. Overall, run $\mathrm{CH} 99$, (forced by ECMWF analyses) successfully reproduces the observed ozone in the lower stratosphere for the cold Arctic winter 1999/2000 (see also Sects. 4.1 and 4.2).

4.4 Arctic $\mathrm{O}_{3}$ loss in 2002/2003 and 2003/2004: comparison with sondes

Figure 13 shows a comparison of the $2.8^{\circ} \times 2.8^{\circ}$ resolution SLIMCAT simulations with $\mathrm{O}_{3}$ sondes at $\mathrm{Ny}$-Ålesund for 

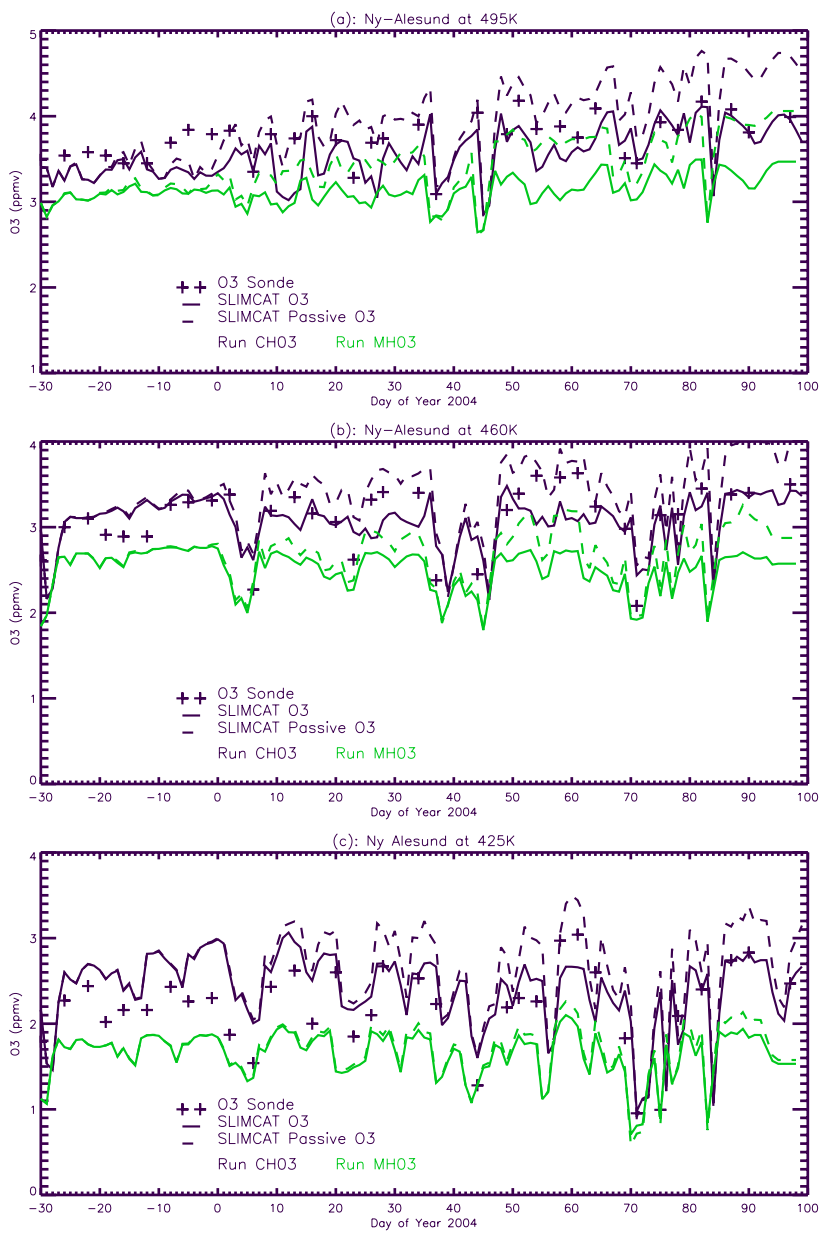

Fig. 14. Same as Fig. 13 but for Arctic winter 2003/2004. Here SLIMCAT runs $\mathrm{CH03}$ (CCM, high resolution) and MH03 (MIDRAD, high resolution).

Arctic winter 2002/2003. The results from the low resolution simulations (run ML and CL) are not shown here as the results are similar to Fig. 12. For this year there is only a small difference $(<0.1 \mathrm{ppmv})$ in the early December ozone value between runs $\mathrm{CHO2}$ and $\mathrm{MHO2}$ (initialised from runs ML and CL, respectively) after 13 years run. However, the winter/spring evolution of ozone using different radiation schemes is again very different.

The run using the CCM radiation scheme (run $\mathrm{CH} 02$ ) is in good agreement with ozone observations for winter 2002/2003. The observed sudden change in ozone around mid February (day 45) and mid March (day 75) in the lower stratosphere is due to the stratospheric sudden warming and more disturbed polar vortex (see Figs. 1 and 2). The large observed decrease in ozone around mid February below $460 \mathrm{~K}(\sim 18 \mathrm{~km})$ is due to the vortex moving away from $\mathrm{Ny}-$ Ålesund and is characteristic of mid-latitude air.

The higher resolution run $\mathrm{CH} 02$ still shows large loss $(\sim 1.1 \mathrm{ppmv})$ in the lower stratosphere in the winter
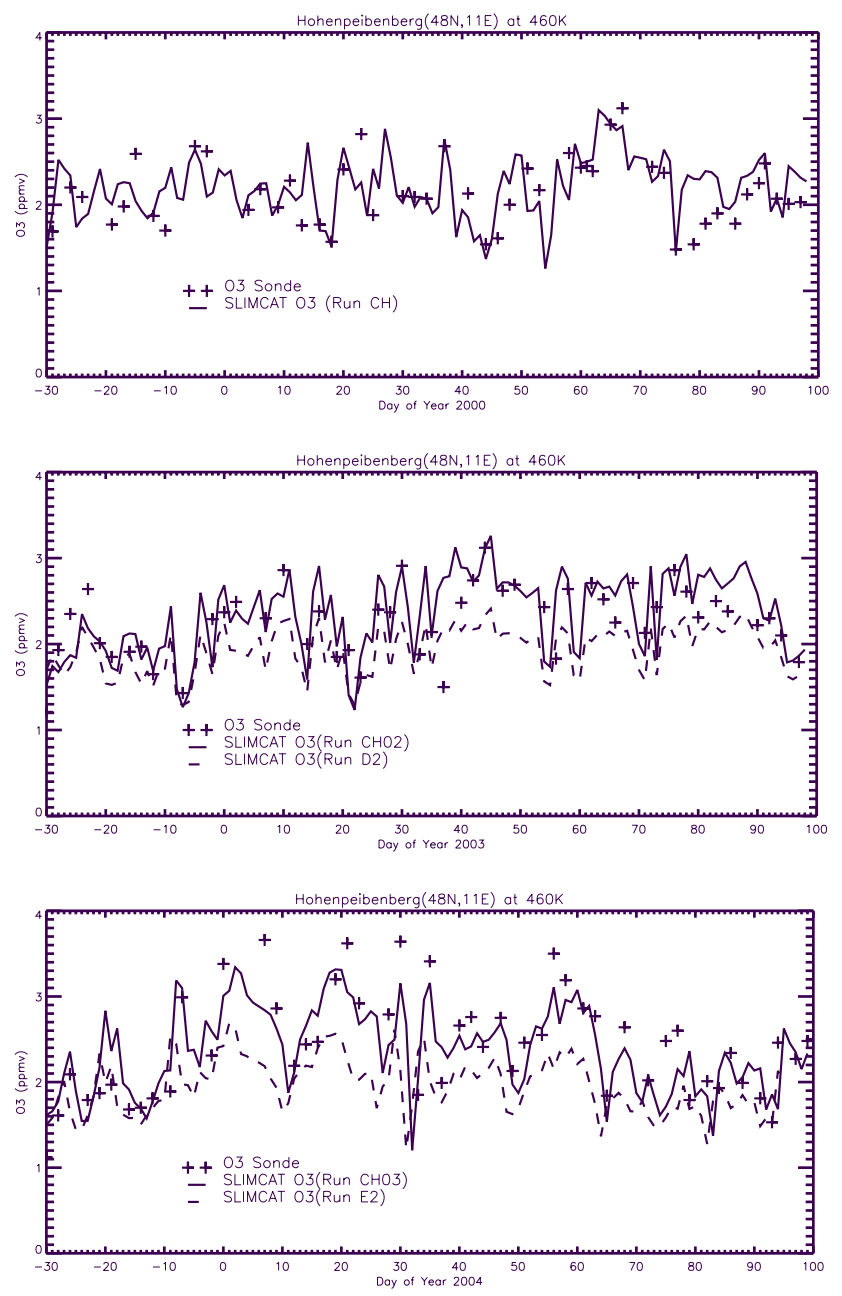

Fig. 15. Comparison of ozone sonde observations (+) at $460 \mathrm{~K}$ at Hohenpeißenberg $\left(48^{\circ} \mathrm{N}, 11^{\circ} \mathrm{E}\right)$ with SLIMCAT $2.8^{\circ} \times 2.8^{\circ}$ resolution simulations for three Arctic winters (top: 1999/2000, middle: 2002/2003, bottom: 2003/2004). The solid lines use the CCM radiation scheme and the dashed lines use the MIDRAD radiation scheme.

2002/2003. Interestingly, earlier ozone loss in December 2002 also can be seen here if compared with 1999/2000 Arctic winter. Figure 8 shows that the Mk IV balloon instrument detected evidence for $\mathrm{Cl}$ activation on the flight of $16 \mathrm{De}$ cember 2002 around $23 \mathrm{~km}$. This supports the model results of activation and $\mathrm{O}_{3}$ loss, although in the model the $\mathrm{HCl}$ removal extends over a deeper region.

Figure 14 shows the equivalent comparison of ozone in the 2003/2004 Arctic winter. The observed $\mathrm{O}_{3}$ levels in 2003/2004 are larger than the other colder winters discussed here (i.e. 1999/2000 and 2002/2003 in Figs. 12 and 13). Overall, the higher resolution SLIMCAT simulation reproduces the observed $\mathrm{O}_{3}$ levels in the lower stratosphere well for the warm and disturbed winter 2003/2004, but there is noticeable discrepancy around the period when the vortex 
becomes more weak and disturbed (days 55 and 70). Model results show about $0.6 \mathrm{ppmv}$ ozone loss at $460 \mathrm{~K}$ between 1 December and the end of March.

\subsection{Comparison with midlatitude $\mathrm{O}_{3}$ sonde data}

For the 3 winter studies we show a brief comparison with ozone observations at mid-latitudes. Figure 15 shows comparison of $\mathrm{O}_{3}$ between sonde observations and highresolution simulations at Hohenpeißenberg $\left(48^{\circ} \mathrm{N}, 11^{\circ} \mathrm{E}\right)$ for the three winters (see Table 1). The observed $\mathrm{O}_{3}$ at middle latitudes is clearly larger in 2003/2004 than for the other two years. Significant changes in ozone were observed at Hohenpeißenberg in the three years at $460 \mathrm{~K}$. However, the model shows that these are dynamical effects - the difference between the model $\mathrm{O}_{3}$ and the passive $\mathrm{O}_{3}$ (not shown) is still very small in this period.

\section{Conclusions}

We have used the recently updated SLIMCAT 3-D off-line CTM to study Arctic ozone loss in winter 2002/2003 and compare it with the very cold winter of 1999/2000 and the warm, disturbed winter 2003/2004. We have tested different radiation schemes in the model and performed experiments at different resolutions. These different radiation schemes and resolutions result in different tracer transport and polar ozone loss. For the new version of SLIMCAT used here, which extends down to the surface, the more detailed CCM radiation scheme produces more accurate tracer transport in the cold winters 1999/2000 and 2002/2003 and produces a better simulation in mid-latitude region. The higher resolution model gives more reasonable transport and mixing than the lower resolution.

The CTM results show that very early chemical ozone loss occurred in December 2002 due to extremely low temperatures and early chlorine activation in the lower stratosphere. Thus, chemical loss in this winter started earlier than in the other two winters studied here. In 2002/2003 the local polar ozone loss in the lower stratosphere was $\sim 40 \%$ before the stratospheric final warming. Larger ozone loss occurred in the cold year 1999/2000 which had a persistently cold and stable vortex during most of the winter. For this winter the current model, at a resolution of $2.8^{\circ} \times 2.8^{\circ}$, can reproduce the observed loss of over $70 \%$ locally. In the warm and more disturbed winter 2003/2004 the chemical $\mathrm{O}_{3}$ loss was generally much smaller, except above $620 \mathrm{~K}$ where large losses occurred due to the period of very low minimum temperatures at these altitudes.

Overall, the best version of the updated model presented here gives a realistic representation of $\mathrm{O}_{3}$ and inferred $\mathrm{O}_{3}$ loss for a selection of winters. This is an advance over earlier versions of our model and other published studies, and shows that our ability to reproduce polar ozone loss is becoming more quantitative.

Acknowledgements. We are grateful for use of the VINTERSOL campaign data. This work was supported by the UK Natural Environment Research Council and by the EU TOPOZ III and QUILT projects. The ECMWF analyses were obtained via the British Atmospheric Data Centre. The authors acknowledge the helpful comments made by the reviewers and K. Krueger. We thank M. Evans for useful discussions.

Edited by: K. Carslaw

\section{References}

Brasseur, G. P., Tie, X., and Rasch, P. J.: A three-dimensional simulation of the Antarctic ozone hole: Impact of anthropogenic chlorine on the lower stratosphere and upper troposphere, J. Geophys. Res., 102, 8909-8930, 1997.

Briegleb, B. P.: Delta-Eddington Approximation for Solar Radiation in the NCAR Community Climate Model, J. Geophys. Res., 97, 7603-7612, 1992.

Burkholder J. B., Orlando, J. J., and Howard, C. J.: Ultravioletabsorption cross-sections of $\mathrm{Cl}_{2} \mathrm{O}_{2}$ between 210 and $410 \mathrm{~nm}$, J. Phys. Chem., 94, 687-695, 1990.

Chipperfield, M. P.: Multiannual simulations with a threedimensional chemical transport model, J. Geophys. Res., 104, 1781-1805, 1999.

Chipperfield, M. P.: A three-dimensional model study of longterm mid-high latitude lower stratosphere ozone changes, Atmos. Chem. Phys., 3, 1-13, 2003,

SRef-ID: 1680-7324/acp/2003-3-1.

Chipperfield, M. P. and Jones, R. L.: Relative influences of atmospheric chemistry and transport on Arctic $\mathrm{O}_{3}$ trends, Nature, 400 , 551-554, 1999.

Chipperfield, M. P., Santee, M. L., Froidevaux, L., Manney, G. L., Read, W. G., Waters, J. W., Roche, A. E., and Russell, J. M.: Analysis of UARS data in the southern polar vortex in September 1992 using a chemical transport model, J. Geophys. Res., 101, 18 861-18 881, 1996.

Davies, S., Chipperfield, M. P., Carslaw, K. S., Sinnhuber, B. M., Anderson, J. G., Stimpfle, R. M., Wilmouth, D. M., Fahey, D. W., Popp, P. J., Richard, E. C., von der Gathen, P., Jost, H., and Webster, C. R.: Modeling the effect of denitrification on Arctic ozone depletion during winter 1999/2000, J. Geophys. Res., doi:10.1029/2001JD000445, 2002.

Feng, W., Chipperfield, M. P., Roscoe, H. K., Remedios, J. J., Waterfall, A. M., Stiller, G. P., Glatthor, N., Hopfner, M., and Wang, D.-Y.: Three-Dimensional Model Study of the Antarctic Ozone Hole in 2002 and Comparison with 2000, J. Atmos. Sci., in press, 2005.

Goutail, F., Pommereau, J.-P., Phillips, C., et al.: Depletion of column ozone in the Arctic during the winters of 1993-94 and 199495, J. Atmos. Chem., 32, 1-34, 1999.

Grooß, J.-U. and Müller, R.: The impact of mid-latitude intrusions into the polar vortex on ozone loss estimates, Atmos. Chem. Phys., 3, 395-402, 2003,

SRef-ID: 1680-7324/acp/2003-3-395. 
Guirlet, M., Chipperfield, M. P., Pyle, J. A., Goutail, F., Pommereau, J. P., and Kyro, E.: Modeled Arctic ozone depletion in winter 1997/1998 and comparison with previous winters, J. Geophys. Res., 105, 22 185-22 200, 2000.

Hansen, G., Svenoe, T., Chipperfield, M.P., Dahlback, A., and Hoppe, U.P.: Evidence of substantial ozone depletion in winter 1995/96 over northern Norway, Geophys. Res. Lett., 24, 799802, 1997.

Hanson, D. and Mauersberger, K.: Laboratory studies of the nitric acid trihydrate: Implications for the south polar stratosphere, Geophys. Res. Lett., 15, 855-858, 1988.

Joseph, J. H., Wiscombe, W. J., and Weinman, J. A.: The DeltaEddington approximation for radiative flux transfer, J. Atmos. Sci., 33, 2452-2459, 1976.

Konopka, P., Steinhorst, H.-M., Grooß, J.-U., Günther, G., Müller, R., Elkins, J., Jost, H.-J., Richard, E., Schmidt, U., Toon, G., and McKenna, D. S.: Mixing and ozone loss in the 1999-2000 Arctic vortex: Simulations with the three-dimensional Chemical Lagrangian Model of the Stratosphere (CLaMS) J. Geophys. Res., 109, doi:10.1029/2003JD003792, 2004.

Krämer, M., Müller Ri., Bovensmann, H., et al.: Intercomparison of stratospheric chemistry models under polar vortex conditions, J. Atmos. Chem., 45, 51-77, 2003.

Manney, G. L., Froidevaux, L., Waters, J. W., et al.: Chemical depletion of ozone in the Arctic lower stratosphere during winter 1992-93, Nature, 370, 429-434, 1994.

Naujokat, B. and Grunow, L.: The stratospheric Arctic winter 2002/03: Balloon flight planning by trajectory calculations, Proceedings of the 16th ESA Symposium on European Rocket and Balloon Programmes and Related Research, St. Gallen 2003 (ESA S2314 SP-530), 421-425, 2003.

Prather, M. J.: Numerical advection by conservation of secondorder moments, J. Geophys. Res., 91, 6671-6681, 1986.

Rex, M., Salawitch, R. J., von der Gathen, P., Harris, N. R. P., Chipperfield, M. P., and Naujokat, B.: Arctic ozone loss and climate change, Geophys. Res. Lett., 31, L04116, doi:10.1029/2003GL018844, 2004.
Riediger, O., Volk, C. M., Strunk, M., and Schmidt, U.: HAGAR - a new in situ tracer instrument for stratospheric balloons and high altitude aircraft, Eur. Comm. Air Pollut. Res. Report, 73, 727-730, 2000.

Sander, S. P., Friedl, R. R., Ravishankara, A. R., et al.: Chemical kinetics and photochemical data for use in atmospheric studies, Evaluation no. 14, JPL Publ., 02-25, 2003.

Shine, K. P.: The middle atmosphere in the absence of dynamical heat fluxes, Q. J. R. Meteorol. Soc., 113, 603-633, 1987.

Sinnhuber, B. M., Chipperfield, M. P., Davies, S., Burrows, J. P., Eichmann, K. U., Weber, M., von der Gathen, P., Guirlet, M., Cahill, G. A., Lee, A. M., and Pyle, J. A.: Large loss of total ozone during the Arctic winter of 1999/2000, Geophys. Res. Lett., 27, 3473-3476, 2000.

Stowasser, M., Oelhaf, H., Ruhnke, R., Wetzel, G., Friedl-Vallon, F., Kleinert, A., Kouker, W., Lengel, A., Maucher, G., Nordmeyer, H., Reddmann, T., Trieschmann, O., von Clarmann, T., Fischer, H., Chipperfield, M.P.: A characterization of the warm 1999 Arctic winter by observations and modelling: $\mathrm{NO}_{y}$ partitioning and dynamics, J. Geophys. Res., 107, 4376, doi:10.1029/2001JD001217, 2002.

Swinbank, R. and O'Neill, A.: A stratosphere-troposphere data assimilation system, Mon. Weather Rev., 122, 686-702, 1994.

Toon, G.: The JPL MKIV interferometer, Opt. Photonics News, 2, 19-21, 1991.

Volk, C. M., Riediger, O., Strunk, M., Schmidt, U., Ravegnani, F., Ulanovsky, A., and Rudakov, V.: In situ tracer measurements in the tropocal tropopause region during APE-THESEO, Eur. Comm. Air Pollut. Res. Report, 73, 661-664, 2000.

World Meteorological Organization (WMO): Scientific assessment of ozone depletion: 2002, Global Ozone Res. Monit. Proj. No., 47, UNEP/WMO, Geneva, Switzerland, 2003. 